\title{
Society and Law Enforcement Personnel in Trading Stolen Goods
}

\author{
The Linkage of the Pendrikan Lor People and Law Enforcement Officials \\ Regarding the Phenomenon of Kokrosono Street Vendors Along Madukoro \\ Street as a Place for Trading Stolen Goods
}

\author{
Septhian Eka Adiyatma ${ }^{1} \otimes$, Naufal Giri Purwoko², Finna Maessy Pangestika ${ }^{3}$, Dewi \\ Kandiati $^{4}$ \\ 1,4 Faculty of Law, Universitas Negeri Semarang, Indonesia \\ 2,3 Crime and Society Research Study, Semarang, Indonesia \\ @ septhianekaa@gmail.com
}

\begin{abstract}
The existence of violating public order, as well as violation activities in accordance with article 480 of the Criminal Code are the characteristics of Kokrosono traders. The provisions of the article refer to criminal relief measures in terms of helping perpetrators of theft crimes obtain benefits from the results of their actions. The uniqueness of merchandise on Jalan Madukoro is that some traded goods are stolen goods. Capital of confidence in the thief makes the stock of stolen goods from the perpetrators of theft is always there. In this case, thieves and stolen merchants can automatically be subject to criminal penalties because there is an intentional element in them, different from the buyer who must be investigated first. This behavior can only be overcome with two channels, namely legal channels and non-legal channels. The legal route leads to regulations related to the detention activities in criminal law and to the extra-legal channels only as countermeasures before the event occurs. Significant differences regarding countermeasures between after and before are in their aftermath.
\end{abstract}

Keywords: Crime; Theft; Trading Stolen Goods; Criminology

\section{Introduction}

Promoting public welfare, is the goal of the Indonesian state listed in paragraph 4 of the opening of the 1945 Constitution of the Republic of Indonesia. The direction for determining the Indonesian state is aimed at making people prosperous, as the hopes of the nation's founders in forming a unitary state of the Republic of Indonesia. With this, Indonesia is obliged to meet the needs of its citizens. Human needs are classified into three (3), namely primary needs, secondary needs and tertiary needs. Only two needs that cannot be separated from all human affairs in terms of survival of life including primary needs and secondary needs. Not with tertiary needs classified as luxury goods.

Meeting the needs does not necessarily arise by itself, there needs to be a certain effort made so that those needs can be met. Like food, needs that cannot be separated from humans. In obtaining it, it is necessary to do business such as cooking alone or buying. Therefore, humans need jobs to get income that is used to get those needs.

Various jobs are carried out for the sake of earning income, do not see that work is permissible or not in accordance with regulations in the country 
of Indonesia to meet these needs. The level of employment in Indonesia that is lacking makes a lot of unemployment in Indonesia. Based on data released by government agencies specifically in the Central Java region in February 2017 it was noted that $4.15 \%$ became unemployed in Central Java Province (BPS Central Java, 2017). Seen from the population in Central Java, which amounted to $34,257,865$, the unemployment rate is quite small (BPS Central Java, 2017). This is because in Central Java province the percentage of jobs offered is quite as much as 17,186,674 in 2017 (BPS Central Java, 2017).

According to the description described above, the unemployment rate in Central Java Province was at $4.15 \%$. But in reality, the population in the province has not yet reached the level of prosperity this can be proven by the large number of street vendors selling along the streets of Semarang. Not only in the city of Semarang, street vendors or commonly abbreviated as street vendors are very often found in Indonesia. The proliferation of street vendors in Indonesia is proof that the field provided does not affect all levels of society.

The presence of street vendors is troubling residents who live around the area of street vendors opening their merchandise, because when there is an order by the Civil Service Police Unit or commonly called Satpol PP there is chaos between officers and traders, this is enough to make the population disturbed. In addition, the presence of street vendors also makes pedestrian rights disappear. Because many street vendors use the sidewalk as a container he conducts his trading activities. Another phenomenon of the presence of street vendors in the city of Semarang, especially in areas along Jalan Madukoro, known as Kokrosono traders, there are street vendors who trade in theft products. Items traded from the results of the theft include such as fans, and also mobile phones. The uniqueness of Kokrosono merchants so that they are not seen as collectors of stolen goods, namely the trading area of Jalan Madukoro - on average are daily necessities ranging from carpentry tools, fans, helmets, to glasses sold there.

At the same context, Sutton (2017) emphasized that thieves steal particular items in order to sell them to buy whatever it is that motivates them to steal. Dealers in stolen goods (fences) function as a buffer between thieves and consumers by reducing the time a thief remains in possession of incriminating evidence, namely the items stolen, while trying to sell them.
Consequently, it is widely believed that the criminological term fence most likely stems from the shortening of "defense" during the 17th century to denote a professional dealer in stolen goods, as someone who is the thief's defense against detection by way of putting themselves in the position of so-called middleman, or dealer. The fence often operates behind a legitimate business "front" as their own proffered defense as an unwitting buyer of ill-gotten gains. Openly buying from such a trader effectively protects consumers of stolen goods from prosecution for knowingly buying stolen goods. "Stolen goods markets" is an umbrella term for specific subtypes of stolen goods outlets, identified by criminologists. Not all stolen goods markets are operated by fences. Some involve the thief selling goods directly to the public, or through an innocent third party such as an auction house or website. Thieves obviously know that stolen goods markets exist. That simple knowledge has been understood for centuries to play a general motivating role in theft, as most prolific thieves do not steal goods for their own consumption.

In legal regulations in Indonesia, such sanctioning activities are prohibited according to article 480 of the Indonesian Criminal Code (KUHP). Article 480 of the Criminal Code outlines the actions taken by traders by selling stolen goods accumulated as a crime relief, based on the sound in paragraph one, namely, "Whoever buys, rents, exchanges, accepts pawning, accepts gifts, or withdraws profits, sells rents, exchanges, providing, transporting, storing, or fitting should be suspected, that it was obtained because of a crime "and in paragraph 2 reads" Whoever draws profits from the results of something that is known or duly should be suspected, that was obtained because of a crime ". From the description of the sound of the two verses in article 480 of the Criminal Code it is clear that traders and buyers can be punished based on the applicable rules, especially if it is known that the goods are stolen goods.

As a state of law (article 1 paragraph 3 of the 1945 Constitution of the Republic of Indonesia) enforcing the force of law must be prioritized to achieve order and order in the Indonesian community. But in reality, the lack of public compliance with the law has caused the detainees in Kokrosono to exist today. The main cause actually leads to perpetrators of theft crimes, rampant acts of theft of theft resulting in goods distributed to the 
Kokrosono merchant market will always remain there.

Then the criminal offense selling stolen good (heling) is an act committed after the completion of the crime against wealth through goods obtained through the crime, it can be said to help or facilitate the crime simply the perpetrator of the crime can expect that the goods stolen, stolen, or darkened will be accommodated by observers which will make it difficult to investigate the relevant crime (Prodjodikoro, 2986). It is very clear that to solve this problem leads to evil behavior or evil deeds in criminal law or formulated in criminal regulations (Dirdjosisworo, 1976). This deterrent crime is centered on the element of deliberation because in every transaction carried out by the perpetrators of the theft of stolen goods traders is only based on the principle of trust, it is clear if using the principle of trust can be explained that prior to the agreement to purchase the goods the trader already knew that the goods were the result of goods theft. Unlike the buyer of goods from the container, the buyer is subject to criminal penalties depending on the results of the investigation by the police. Because the person hiding the truth about the origin of the goods being traded.

Must go through law enforcement in solving this crime problem. Criminal law is a positive legal effort in Indonesia because it is only a strict criminal law in dealing with crime that is troubling the public. Then it can be described in outline efforts to tackle crime can be divided into two, namely the path of punishment (criminal law) and through the non-criminal pathway (not/outside of criminal law). Efforts to tackle crime through the panel route focus more on the nature of "repressive" (action/eradication/suppression) after the event occurs, while the non-penalty line focuses more on the nature of "preventive" (prevention/mitigation/control) before the crime occurs (Arief, 2010 ).

Traders Kokrosono made the reason the study was aimed at them, because the behavior of the crime relief and camouflage in hiding violations in accordance with the explanation of article 480 of the Criminal Code is a separate value for the basis of conducting research. The emergence of the establishment of street vendors in Jalan Madukoro since 1992 makes evidence that law enforcement in Indonesia is not optimal enough. This research is centered on the observing activities that still occur in the city of Semarang, the views of several related parties are indispensable for the completeness of the observations entitled The Population Relationship of the Pendrikan Lor Population, and Law Enforcement Officials Concerning the Phenomenon of Kokrosono Street Vendors Along Madukoro Street as a Place for Trading Goods Results Stealing.

\section{Method}

\section{A. Research Approach}

The research approach in finding information about the interrelationships between the three parties involved in the impact of the presence of street vendors selling stolen goods is carried out by means of a qualitative approach, this approach is very effective for collecting data on the phenomenon of receptors that occur on Jalan Madukoro.

A qualitative approach is an approach in conducting research that is oriented towards natural phenomena or symptoms.8 Qualitative research is research in which problem solving is carried out using empirical data. The nature of nature is caused because the observation collection technique is done by directly surveying the spaciousness in which the phenomenon occurs. Techniques in collecting data through a qualitative approach, focused on several objects that were the main target to deepen information about the receiver. Conducting open interviews with several representative respondents from all three parties involved as data collection media.

This type of research used in this research is the type of case study. Case study is an approach to study, explain, or interpret a case in its context naturally without any intervention from outside parties. This type of research will immediately apply if there are questions about how and why. The tendency in this case study is that this study seeks to highlight a decision or set of decisions, and why the decision was taken, how it was implemented, and what the results were. And comparative studies are studies by comparing each other, resulting in linkages from one side of the view complemented by the views of the other parties involved.

The reason for using this type of case study research is because the research method used is a descriptive research method, where this qualitative method can be carried out through case studies and comparative studies. Using case studies to 
understand this phenomenon is needed so that the overall starting from the reasons and origins of the system of collecting stolen goods can be known with certainty. Besides the use of comparative studies by comparing the social views of the people around Madukoro St. regarding the activities of Kokrosono traders, the social views of traders in Kokrosono are specifically for the collectors of stolen goods and comparing the views of public order enforcers namely Satpol PP based on this phenomenon. Based on the problem of how the influence of the host and the interrelation of the three parties as described above, the reasons for using case study methods and comparative studies.

In addition to using case studies and comparisons, this research uses literature studies in terms of completing the data in a theoretical study. Literature study is carried out with research conducted through the collection of a number of books, legal journals and several official websites related to the issues raised in this study.

\section{B. Types and Sources of Data}

1. Types of Data

The type of data contained in the study of collectors uses qualitative data presented in verbal form without any presentation in the form of numbers, which are obtained based on qualitative data including explanations relating to the reasons for trading stolen goods still occur on Jalan Madukoro, the participation of surrounding communities from the point of view respondents, and the role of Satpol PP as the apparatus that regulates order.

\section{Data sources}

What is meant by data sources in research are subjects from which data can be obtained (Arikunto, 2006). In this study the authors used two data sources, namely:

1) The primary data source

leads to the object under study, namely Kokrosono traders, the community around Madukoro Street, and the Civil Service Police Unit.

2) Secondary data sources

leads to the results of data that have been received from primary data sources by conducting interview techniques and conducting documentation as evidence.

\section{Data Collection Method}

Research on the traders of Kokrosono was conducted by direct research, namely by observation, interviews and documentation. The first data collection technique was done by observing the spaciousness on Jalan Madukoro. The second data collection technique was carried out by means of open interviews with several respondents, with the election of several representatives from the three parties related to the problem of the presence of nurturers on Jalan Madukoro. Then the third data collection technique is by means of documentation as evidence this research has been carried out, both in the form of writing the results of interviews and photos and videos during the observation activities took place.

In addition to using direct research this observation uses literature study techniques in obtaining relevant theoretical data in discussing collectors in accordance with article 480 of the Criminal Code.

\section{Result and Discussion}

\section{A. Criminological Perspective on Theif and Crime in Society}

\section{Crime and Criminology}

Criminology comes from the English Criminology, etymologically divided into two words including Crimen and Logos. If interpreted one by one, crimen means crime and logos means science, it can be concluded that Criminology means knowledge that studies the problem of crime. Criminology or crime as a social science or non-normative discipline that studies crime in a social way. Criminology is referred to as the study of humans in opposition to certain social norms, so criminology is also referred to as sociology of criminals. Criminology seeks to gain knowledge and understanding of social phenomena in the field of crimes that occur in society, or in other words why the defendant commits his evil deeds (Sahetapy, 1982). The phenomenon of crime becomes the material for studying criminology, in this case, prioritizing crime behavior by paying attention to social interactions between communities.

Enrico Ferri argues that criminology seeks to solve the problem of crime by examining positive and social facts, crime including any actions that threaten the collective and from groups which cause a defense reaction of the people based on their own discretion (Gurvutch, 1961). The function of criminology is expected to be a preventive measure 
against an act of violation so that it does not recur, this is continuous as the basis for taking future actions because criminology provides coverage in its assessment as follows:

a. Studying offenders who commit crimes

b. The cause of the perpetrators of deviant acts

c. Prevents repeated deviations

d. Knowing the impact felt by the victim due to the perpetrator's actions in healing.

According to Sutherland (1960) included in the field of criminology are the processes of making laws, violations of these laws, and reactions to violations of these laws. The scope of criminology covers various aspects related to the Act. Starting from the process of drafting the Act, violation of the Act and the community's reaction to the violation of the Act.

\section{Criminological Theories for Crime of Thief}

The Sub-Culture Theory itself here refers to an act of juvenile delinquency where urbanization (the movement of residents from villages to cities) causes more problems that usually arise in the lower classes and the most obvious form. In the Street Vendors (PKL) sellers of stolen goods themselves there are some traders who come from outside the city of Semarang. Then in our observation study the problem we took turns out to be included in one of the criminological literature, namely, The Differential Opportunity Theory where this theory explains that the orientation of a criminal act or deviation occurs in urban areas, such as the case we take the existence of street vendors (PKL) Kokrosono is located in the middle of the city on Mardukoro Street, Pendrika Lor Subdistrict, Central Semarang. This underlies our linking our case to this theory, The Differential Opportunity Theory itself has three different types of sub-culture material, where Conflict Types Sub Culture is also included in the discussion of this case because the Conflict Sub - Culture itself is a theory that explains that in an unintegrated society tends to show free behavior such as violence, deprivation or theft and other deviant behavior. In our observations we find that the influence of street vendors in Kokrosono itself has an impact on the residents around there who even take part in selling stalls on the shoulder of the roadside, then there are also residents around there who instead become mobile collectors (cellphones) even to commit acts of theft carried out at the place of worship.

\section{Thief Market (Pasar Maling)}

People who think that street vendors selling at Thief Market make a deposit, namely selling stolen goods (Sari, 2017). This market used to be known as a thief market with a bad image that is a lot of pickpockets and places for stolen goods. But in 1990 it became a milestone for the rise and change of the image of the Thief Market. Bad habits are abandoned, and now there is only a market called PM that can be interpreted as the Thief Market, Cheap Market or Night Market. The products offered are still the same, but in addition to low prices, there are still other benefits that can be obtained when shopping at this market. Namely, buyers can get used goods with good quality and low prices. However, after conducting research the researcher wants to refute the community's perception. After doing research, it is known that the name of the Thief Market is obtained because this market is open at night and because that night is the time for thieves to act. Visitors come to the Thief's Market to look for the items they need that are sold at the Thief's Market.

For stockselling goods, for second-hand cellphone sellers they usually buy stock from the flea market, because the cellphones they sell are old cellphones. Where the goods they buy from the flea market are not good or new, they usually fix the broken cellphone first before they resell it. Not only from the Flea Market sometimes there are people who deliberately sell their old cellphones to informants and then can be resold by informants. Street vendors in Thief Market choose good items but which can be sold at bargain prices (Sari, 2017).

\section{Factors Causes of Selling in Kokrosono}

The presence of street vendors became a media job for a group of citizens in Indonesia who do not have a job. There are several aspects that can be used as indicators of the form of street vendors, including (Isrohah, 2015): 15

a. Business activities are not well organized because the emergence of business units do not use the institutions available in the formal sector.

b. Capital and business turnover are relatively small, so that operations will be small too.

c. The pattern of irregular business activities, both in terms of location and working hours.

d. Production results are mainly consumed by the lower middle-income groups 


\section{Stolen Goods Cacther}

Researching a crime must understand human behavior both with a descriptive approach and with a causal approach, in fact today there is no longer an investigation because of the causes of crime, because until now it has not been able to determine the causes of greater or smaller risk carriers in causing certain communities to carry out crime, by seeing how complex human behavior both individually and in groups. Soerjono Soekanto stated, there are two factors that cause crime, namely:

a. Personal factors, including biological factors (age, sex, mental state, etc.) and psychological (aggressiveness, carelessness, and insanity).

b. Situational factors, such as conflict situations, place and time factors.

Other things that can be taken in this criminal offense are generally caused by two things, namely:

a. first, for thieves promising huge profits to sellers of illegal goods or objects obtained from crime.

b. Secondly because of the need to meet the necessities of life and for buyers because the price is so cheap that buyers are tempted by these cheap goods to be bought.

\section{Factors That Cause the Performer}

In this regard, it is necessary to present the opinion of W.F Maramis who states that there are 3 factors why a person conducts detention, namely:

a. Personality Factors

People who have a less stable personality, and have an easy attitude tempted.

b. Socio-Cultural Factors

In Indonesia, apparently the host comes from families with poor socio-economic conditions. People generally underestimate the legal aspect or do not care about the law.

c. Physical factors and habits

There are a number of suspects who carry out the trial for fun. When the suspect is used to doing it the antecedent, then tend to do it again (this kind of tendency is called "positive reinforcement").

Based on the factors mentioned above tends to associate the reasons for someone committing criminal offenses in addition to being for profit also conducting the investigation caused by several factors, namely:

a. Because it is profitable, which is an act done by someone because there are both large and small profits in illegal sales and purchases. b. Because of desire, which is a strong will that drives the offender to carry out detention.

c. Environmental factors, which is a condition that encourages carrying out, especially in association.

d. Because of the habit, which is something that has become a habit in the perpetrators to carry out the retention or addiction as the perpetrator's livelihood.

e. To fulfill the necessities of life, i.e. the sale and purchase of illegal goods is carried out because of the urge to fulfill the living needs of the offender.

f. Opportunity, which is a condition that allows (providing opportunities) or circumstances that support the occurrence of a detachment.

So based on the information above, the deterrence by the convicted person is caused by various factors, including the factors that have been explained by using some of the single factor theories above. Essentially the law is a rule and prohibition to regulate human behavior and is coercive. The law forces in various ways, with direct and indirect intercession, the rule of law is not to warn, encourage or convince, but to govern, force, even though it does not mean that it can always be forced.

\section{Civil Service Police Unit}

The Civil Service Police Unit or commonly known as Bailluw is an organization that is very close to the community, because its main task is to maintain public order and peace of society, has undergone several changes in name in accordance with its development. The term civil service comes from two words namely "pamong" and "praja". Pamong means management, caregiver or educator. Whereas Praja means city, country or kingdom. So that literally Civil Service can be interpreted as a city administrator (Sari, 2010).

Based on the contents of Article 6 PP No. 16 of 2018 concerning the Civil Service Police Unit, Satpol PP has the following authority:

a. Conducting disciplinary measures against members of the community, apparatuses, or legal entities that violate local regulations and / or local regulations

b. Acting on a community member, apparatus or legal entity that disturbs public order and public order

c. carry out investigative actions against members of the public, apparatus, or legal entity 
suspected of violating the Regional Regulations and / or Regional Regulations; and

d. carry out administrative actions against members of the public, apparatus, or legal entities that violate the Regional Regulations and / or Regional Regulations.

In the observation study that we did in Semarang it turned out that the municipal police used 2 (two) local regulations to deal with the problem of street vendors (PKL), namely Regional Regulation No. 11 of 2000 concerning Regulation and Guidance of Street Vendors and SK Mayor / 511.3 / 1112 ratified on 16 December 2016 concerning Land Designation of Semarang City Street Vendor Location in addition to being in compliance with the main regulations in PP No. 16 of 2018. In Perda No. 11 of 2000 there are several sanctions imposed if there are street vendors (PKL) affected by raids divided into 2 (two) provisions, namely: administrative sanctions and criminal sanctions. In dealing with Street Vendors (PKL) in Kokrosono Market, Satpol PP prioritizes administrative sanctions in the form of reprimands or warnings and confiscation. If the first, second and so on warning does not have any effect then a confiscation of merchandise seizure is carried out where the confiscation is temporary but there are several conditions that must be passed if the confiscated merchant can be returned and taken within 10 days in the count after confiscation, with requirements for RT and RW Decree.

\section{B. Criminological Theory of Kokrosono Traders}

Criminology tries to obtain a study in terms of the cause of a person committing a crime, using theories related to an offense or a crime. In criminology, a person will be examined and studied why to do something that is not in accordance with the needs of social life. So criminology is tasked with assisting criminal law in studying the causes of people committing a crime, how the consequences are, and how to eliminate the criminal act (Maramis, 2012) .17 Every human being has the opportunity to commit a crime depending on each individual, this opinion also in line with what was raised by Lambroso who considered Lambroso to say crime was an innate talent of the ancestors. But crime occurs if there are several factors that cause a person to be able to take the opportunity to commit an offense or crime. These factors include (Saherodji, 1980): 18

a. Internal factors Internal factors are factors found in individuals such as Psychise, sex and sex, age / age, physical, flebleminded / mental, Psycal Handicaps, twins / twins, race and family.

b. Exteren Factors Exteren factors are factors that are outside the individual. These external factors are rooted in the individual environment such as: Education, communication (cultural factors, economics, politics, modern social, minority roles) and geography.

In studying criminology, there are several theories that can be used to analyze problems related to crime. The relationship between criminology to the phenomenon of street vendors selling stolen goods and the attractiveness of their presence to the community, can be seen from the theory of criminology, as follows:

\section{From the Terminology Side About Criminology}

In the subject of this observation report, process theory is used in discussing the problem of the relationship between criminology and the thief market. The use of process theory is because in this case there is some elaboration on how a person becomes a villain, Kokrosono traders are basically a group of people who violate the rules of public order. The cause of the prevailing trade in the area is because of the urgent economic needs caused by the lack of human resources. The limited human resources made traders on Jalan Madukoro violate the law. Basically, their process of opening merchandise stalls in areas specifically for general activities, not for trade areas. Very by using this theory, it can be concluded that the economic needs factor which is the background for them to commit deviations. Process Theory can be described in terms of the theory of Under Control, in the theory of under control makes reasoning more in depth than the theory of the process. By describing people breaking the law while most people do not (Mulyadi, 2010). Someone commits deviations while others do not because of economic needs.

\section{From the Side of General Science and Modern Criminal Law About Criminology}

The Sub-Culture Theory discusses and explains the form of juvenile delinquency because the existence of street vendors themselves encourages young people to commit criminal acts such as theft, which in this case can be included in the Differentiial Opportunity Theory literature, namely deviations that occur in urban areas, here 
itself the existence of street vendors (PKL) in Kokrosono is located right on the edge of the Madukoro road and directly adjacent to the recreation park of the West Flood Canal where the bustling city is visited and is passed by local residents. In the description above this case belongs to the Conflict Sub-Culture type because it shows free behavior and the conditions of street vendors (PKL) that cannot be integrated or are irregular even though they are often exposed to raids they still do not give up selling there which causes disorder and makes a slum environment.

\section{Relationships between Law Enforcement, Traders and the Community}

In general we all know that the existence of street vendors (PKL) itself everywhere always brings various problems, because they sell traded goods illegally (out of place) such as selling on the shoulder or side of the road, on the sidewalks and etc. a place that if the place is strategic for selling. Indeed, it brings benefits for sellers but also brings losses for road users such as motorbike riders, cars and pedestrians. In this case the existence of street vendors around the Madukoro road itself has greatly disrupted traffic in the area because in addition to narrow road access plus there geographically there is a railroad doorstop which when the train passes surely all highway users will stop and wait for the portal or an open railroad crossing it has already caused congestion there are also buyers who want to buy goods at street vendors carelessly parked on the side of the road so as to increase the volume of vehicles on the road, besides that there is also because it is located around the Madukoro street where there is a Banjirkanal recreation park West often there is also a water tank truck to water the plants in the recreation park which is also a factor causing congestion around the road.

The above turns out to agree with Mr. Topo as a street vendor along the road that we were interviewing at the time because the presence of street vendors there was not the only reason for traffic jams along Kokrosono. In this case Mr. Topo himself as a street vendor around Kokrosono sells a variety of electronic goods, especially mobile phones, he has been selling since 2001 or 18 years ago, unique here we can think of Mr. Topo as a veteran who has very much memorized all kinds of problems experienced by the PKL Kokrosono, he is also considered a veteran because for 18 years of selling there he has never been hit by raids from
Satpol PP at all. Mr. Topo as a seller of all types of conditions such as lcd phones, cell phones die, resale, blisters, damaged and others, Mr. Topo get the cell phone from various people without looking at the background of the condition of the cell phone is obtained, by what means the cellphone is obtained, where it came from The cellphone was obtained. Because a lot of demand and many people who are looking for cheap cellphones usually in a month can sell 20-25 units of HP in all conditions.

The implementation of law enforcement is not always in accordance with what is written in the legislation. Progress in the field of technology and information at this time a lot of influence the social system in society. One of them is the economic changes that have worsened due to the impact of the global crisis that has hit almost all parts of the world, including the State of Indonesia. With the high economic pressure that demands everyone to meet their every need. Individuals in carrying out businesses to meet their needs must interact among other community members (Yuliana, 2019).

Economic incentives are drivers of crime. Durability, usually referred as the inverse of the speed at which quality deteriorates, is an important feature of the quality of the goods that is valued by consumers and affects the prices they are willing to pay for them. Acquisitive crimes have mostly the purpose of selling the stolen goods. Therefore, durability affects the incentives of prospective criminals to steal durable goods. In fact, most of the crime is property crime, and mainly involves durable goods, which are not consumed or destroyed and can be used for a period of time and are therefore costlier. The most popular of those are smartphones (Galiani, 2018).

The big question here is where did the cellphone come from? When we observe these questions and answers we use qualitative research methods where data is obtained through direct sources or those in the field we know that usually the people who sell cell phones in Mr. Topo's stalls are mostly from the general public such as parents and adolescents and incidentally we got the right time because at that time Mr. Topo was dealing with one of the nurturers who had subscribed or had often sold and supplied the HP stock that was traded. Topo himself is also a native of Semarang, Mas Gombloh when we ask where his cellphone came from, he plainly and shamelessly answered if the cellphone was obtained from the results of stealing in a mosque or mosque and also the cellphone was obtained from his friends who sell 
cellphones like that also later bought and d sell again. The target of Mas Gombloh when he stole his cellphone in the mosque or mosque was that he had memorized the condition and condition of the mosque or mosque like there were no surveillance cameras (CCTV) then the mosque was deserted. This must be very alarming and make people anxious or alert to acts of theft carried out around the Mosque and Mosque around the city of Semarang, when we dig deeper to find data Mas Gombloh at that time rushed to leave because there were other needs. When we ask again about the source of the cell phone that was obtained to $\mathrm{Mr}$. Topo he immediately emphasized that if in his cell phone sales booths it was not just anyone who could hand over or sell his cellphone because:

a. First, if you have known a long time like Mas Gombloh, Mr. Topo just immediately accepted the cellphone and did not know where the cellphone was obtained because it was based on trust.

b. second, if the seller of the cellphone is the first person to sell the cellphone in the lap of Mr. Topo he will ask for guarantees such as photos of the seller's face or photo ID card, this is done by Mr. Topo to form the initial foundation of trust if for example the cellphone being sold is indeed safe and there is no problem with the authorities.

In both of these reasons, Pak Topo only wanted to make sure if there were problems related to the goods that he bought and sold with the authorities, he could immediately find out where the phone was from, such as Mr. Gombloh who had subscribed and Mr. Topo also knew very well where his house was. there is a problem Mr. Topo can directly meet or look for it, as well as the second condition if there is a problem Mr. Topo just needs to provide a face photo or a KTP photo from the HP seller who was first selling his goods at Mr. Topo's shanties.

In addition to Mr. Topo as a Street Vendor (PKL) Mobile Seller (HP) there is also Mr. Moejono and Mr. Beni as a Street Vendor (PKL) who sell used goods or collapsing artisan tools such as hammers, screwdrivers, meters, etc. other, then there are also electronic equipment such as fans, Handy Talky (HT), Irons and others. When we dig up the question and answer interview data further, it turns out that Pak Moejono is not a native of Semarang, he is originally from Klaten and has been selling the goods for five years in the Kokrosono area, Mr. Moejono is looking for the items he sells usually to the robber or to people others who want to sell equipment in all conditions, unlike Pak Topo who insisted on asking for a face photo or ID card for the seller of the goods, Mr. Moejono accepted all items sold to him as long as the price matched. Pak Moejono can usually produce 300 thousand a week and the most crowded are usually on Sundays. From the various data we have obtained, it can be concluded that the street vendors (PKL) in Kokrosono do not care about where their merchandise is obtained, the most important is the results of their sales because of the economic need to sustain life.

The popularity of buyers in Kokrosono is very influential. Consumer behavior is an action that is directly involved in obtaining, consuming, and consuming products or services, including the decision process that precedes and follows this action (Setiadi, 2003). The existence of street vendors in the Maling Market is increasingly gaining recognition from the public. Recognition from this community is characterized by a market that is always crowded with visitors even on Saturdays and Sundays (Sari, 2010). Consumers and markets are two things that can not be separated in the process of sales and fulfillment of needs. The market without consumers can not run, so consumers need the market as a place to meet needs. The market can influence consumers to come and buy consumer needs. Many factors can affect consumers to be used as a place to meet needs. According to Kotler and Armstrong's theory there are five factors that most influence consumers in consuming goods, namely: price factors, quality factors, education factors, service factors and promotion factors. Maling Market as a market has various factors that can influence consumers to bring in consumers. Consumer ratings of goods sold in the Maling Market have two ratings, namely goods that have quality and goods that have prices. The quality of goods sold in the Maling Market has three categories based on respondents' answers, namely goods of good quality, medium quality and poorquality goods. The quality of goods is a factor influencing consumers to choose the Thief Market, a figure of $75.3 \%$ of all respondents said the goods sold at the Thief Market have good quality so consumers are interested in coming. The quality factor of goods does influence consumers to come to the Maling Market, but the biggest factor influencing consumers to choose the Maling Market based on the results of the study is the price factor of the goods sold there. Figures of $93 \%$ of all 
respondents indicate that consumers are interested and choose the Maling Market as a place to meet their needs because the price of goods sold there is cheap (Wiyasa, 2014). We also conducted a data search by interviewing one of the buyers, namely Pak Surwawi who is a citizen of Semarang City who said he often buys equipment here, Pak Surwawi also knows that here there are many unclear origins so he prefers to buy goods from traders who have long known or subscribed to avoid if a problem occurs. Pak Surwawi chooses to buy goods here often because a lot of goods are still suitable for use but the price is very cheap.

In the conclusion of the data we can actually have a positive and negative influence on the existence of street vendors (PKL) stolen goods sellers in Kokrosono. Street vendors in the thief market sell used goods such as mobile phones, shoes, bags and other electronic goods with various well-known brands. For the Positive Influence of the existence of Street Vendors, it is actually helpful for buyers when they want to look for handyman tools, for example, with low prices and conditions that are still suitable for use. Usually those looking for these items are builders. Whereas for electronic devices such as cellphones are sought after by the general public because now people certainly have cellphones as the main communication tool, street vendors (PKL) in Kokrosono itself provide lots of all types of cellphones, as well as all conditions of cellphones at relatively cheap prices from 50,000.00 $1,000,000.00$, there also sell ORI mobile accessories and components such as Hp batteries or chargers that are very cheap and affordable. For its own negative influence, as already mentioned above the existence of street vendors (PKL) itself causes road problems namely Congestion and seizure of pedestrian rights because of the existence of street vendors (street vendors) using sidewalks or roadside shoulders for the area to set up their merchant stalls. . Its existence actually also makes a dirty impression for people who see it because it is irregular and arbitrarily sell themselves there, local residents are also resigned because on the side of the highway is the business and responsibility of the government here, Satpol PP which is tasked with curbing the street vendors (PKL) is in accordance with applicable regulations. Residents can only act if for example the street vendors sell in the village complex area. residents act by making their own evictions.
In addition, the existence of PKL Kokrosono also had a negative impact on residents around the area, such as the incident above Mas Gombloh who as residents around there became deviant behavior due to the theft because of being influenced and tempted by economic opportunities, and Mr. Topo, who had been selling there for 18 years, this has a negative impact on the mindset of the citizens.

\section{The Relationship Between Law Enforcement, Traders and the Community}

In the street vendor (PKL) activities at Kokrosono Market, attracting several related parties, namely law enforcement or authorities, traders and the surrounding community. These parties have a significant relationship. Traders who commit crimes must be immediately dealt with by the relevant law enforcement officers, as well as the role of the community in helping authorities who directly feel and see the crime. This shows the important role of the authorities to handle the Kokrosono Market problem. Actions to be taken must consider various aspects. To ensure the actions taken by the authorities, the results of interviews conducted with Satpol PP together with Mr. Eko Suroyo and Mr. Kansi Munawir as officers handling illegal street vendors (PKL). Pak Eko and Pak Kansi said the Kokrosono Market was inappropriate and not allowed. Satpol PP handles the problem of street vendors using related regulations, the use of regulations as a basis for action is only aimed at street vendors who do not have permission to open their merchandise. Perda No. 11 of 2000 regulates criminal provisions against street vendors who do not have licenses other than that, they also regulate the rights, obligations and prohibitions of street vendors if they violate, so in article 12 the threat of imprisonment is given for a maximum of 6 months or a maximum fine of Rp. 5,000,000 (five million rupiah). In dealing with Street Vendors (PKL) in Kokrosono Market, Satpol PP prioritizes administrative sanctions in the form of reprimands or warnings and confiscation. If the first, second and so on warnings do not have an effect, a temporary seizure of the confiscation of merchandise. Confiscated goods can be returned and taken within 10 days of confiscation, on the condition that there is a RT and RW Decree. Goods are released every Friday. However, there is a difference here between traders who were first hit by raids and traders who have been repeatedly hit. For the first-time trader, confiscated goods can be 
returned according to the stipulated provisions, but for traders who have been exposed many times the item cannot be taken back. But the weakness in the system is that the Satpol PP at the time of collection or confiscation of goods did not have time to identify and do not have records related to traders who have been recently or have repeatedly been hit by raids. Despite the critical importance of this phenomenon, there has been no systematic empirical investigation of the effects of stolen goods markets on crime. Two main obstacles hinder such an analysis. First, markets for stolen properties are hard to identify. Secondly, these markets are not randomly assigned to geographic locations (D'Este, 2014).

Traders who are not domiciled at the crime scene must then ask for a letter to the crime scene, the Kelurahan, and the place of residence. Signed letters must also be stamped. Satpol PP has the task of assisting the Mayor in organizing regional government in the field of peace and order and enforcement of regional regulations. So that the role of Satpol PP as an implementation actor is in the context of enforcing regional regulations and realizing order and peace (Saputro, 2013). Satpol PP is only tasked with carrying out control, but Satpol PP has no routine schedule in carrying out control. It's just that if there are reports from the public regarding the market that it has disturbed order and violations occur, then at any time Satpol PP conducts operations. Because the operation is done suddenly, there is no chance for the trader to find out (connection). This opinion is inversely proportional to merchant Kokrosono who said that having connections so that 18 years had never been hit by a raid. According to Satpol PP officers, it is possible that the trader has special skills so that he is never caught. Satpol PP has 2 (two) ways of jump operations, namely at the time of jumping and finding a street vendor (PKL) that has not been interfering with errors then the goods can be returned, and secondly there is coordination of the area with the first warning, second warning, warning and up to confiscation. According to Perda, Satpol PP only carries out public order, if there is anyone who makes uneasy and noisy then warns or asks if there is a commotion. In the case of motorcycle theft, Satpol PP is not authorized to enter the realm, the authority to handle is the police because Satpol PP only helps to secure the cause of the realm of Regional Regulation.

Not only Satpol PP, there were also results of interviews with local residents and RT heads in the
Kokrosono Market environment. Here we interview Mr. Zuliawan Chairperson of RT04 RW06 Pendrikan Lor Village. He feels that the existence of street vendors in Kokrosono itself actually makes slums along the Madukoro road and sometimes causes traffic jams because of selling on the side of the road, but Mr. Zul (his familiar greeting) also do not mind if the street vendors sell by the side of the road, because the area is the responsibility of the City Government especially the Satpol PP who is tasked with executing it or those who regulate it, Pak Zul has objections if there are street vendors selling in the Alley or Kampung Entrance. a meeting with Street Vendors (PKL) and produce a joint decision where the point is:

a. Street vendors cannot sell into the Gang Village

b. If street vendors sell in the Village Gang and disturb local residents will be expelled

c. All matters of the stalls are taken care of themselves and the RT will not be responsible if there are problems with the authorities

Pak Zul himself said that now there are no citizens who participate in selling in Kokrosono because it has been appealing properly. and there are no Adolescents or Parents who become thieves or collectors of stolen goods related to Kokrosono because residents RT03 RW06 have always agreed not to participate in or deal with the authorities because there was once one of its citizens affected by the case to be a Parts Observer (Motorcycle engines and components) from stolen motorbikes or motorcycle jackets so that it makes local residents aware if they do not want to deal with the authorities.

In this case there was a different opinion expressed by Pak Prasetya, Chairman of RT03 RW06 Kelurahan Pendrikan Lor, his nickname was Mr Pras with Pak Zul's opinion. Pak Pras himself even allowed some street vendors to sell into the Gang or the RT entrance, but still with several conditions such as:

a. Cannot disturb the surrounding residents who are active

b. Keep the environment clean selling

c. Not selling illicit goods (Drugs, Pills)

Pak Pras is of the opinion that he allows some street vendors to sell there because of compassion related to the economic need to earn a living but it does not rule out the possibility if for example both parties have entered into a kong kong kong times themselves. He said the Street Vendors (PKL) had been selling for a long time on the side of the road or into the Gang Village, apparently this 
affected or encouraged local residents who were actually selling goods like that. Many RT residents of Pak Pras himself have also been affected by cases as stolen goods collectors, ranging from motorbikes, cellphones, and helmets. Even though many local people have been affected by the problem, it does not provide a deterrent effect to the other parties. Mr. Pras himself also found that residents who sell in Kokrosono turned out to be migrants from outside the area who rented houses or boarding houses, such as Mr. Moejono who came from Klaten so there was no end.

The connection between street vendors (PKL) who violate public order becomes the task of Satpol PP to discipline and give warning or warning. Because the place of the crime is also related to the peace and well-being of local residents. Satpol PP relocates in coordination with the Trade Office. Factors affecting the regulation and guidance of street vendors by the Civil Service Police Unit include internal factors including the development of human resources, inadequate facilities and infrastructure and legal instruments that are not yet available, while external factors such as public legal awareness, especially the street vendors are still low and coordination or crosssectoral support from other relevant agencies is still lacking, so it is very difficult for the Civil Service Police Unit (Mardiani, et.al., 2018). Illegal street vendors (street vendors) have become a culture, these cultures can be lost because of awareness, and therefore it takes positive thinking from these traders. Although it has been facilitated, but the facility is not utilized properly. There is a significant positive relationship between perceptions about the reputation of Satpol PP officers and compliance with street vendors. This means that the better or more positive perception about the Satpol PP officers' reputation, the higher compliance of street vendors, and vice versa (Monika, et.al., 2014). Because of the demands of the economy, the community will do anything to get a decent living. Although doing a crime that can harm many people. Control of Street Vendors (PKL) in Kokrosono Market is indeed needed, so that peace can be created in the community. The role of Satpol PP or the authorities is very important, to provide appropriate facilities and maintain public order in the community. The City Government intends to regulate and discipline street vendors so that their presence can benefit the lives of city residents by avoiding as much as possible the emergence of negative aspects through a policy, namely occupying on sidewalks and fragments of roads that have been determined with the area and time spent predetermined. In the city of Semarang, the arrangement of street vendors' businesses that occupy vacant land, fragments of roads or other public facilities is regulated by the Mayor's Decree (Widodo, 2000).

\section{Conclusion}

Judging by the theory of the process of the existence of street vendors (PKL) in Kokrosono arises or is due to the habits of local residents who have always been selling at locations around there and influenced by economic needs. This shows that the lack of quality of the Human Resources of residents around the PKL Kokrosono because it actually continues the activity and is not cured with the consequences it faces. Because of the existence of street vendors (PKL) which have long been selling at the side of the Madukoro road, new problems have arisen, such as the act of holding stolen goods, theft and others.

The presence of street vendors (PKL) Kokrosono provides positive and negative impacts, the positive impact of the existence of street vendors there brings choices for local residents who want to look for low-priced goods with good conditions but it is unclear where the goods originate from. must be considered with the buyer to be selective in buying goods there, low prices do not guarantee that the goods are normal or feasible to use especially if it is electronic goods. Like our observation to Pak Surwawi, he chose to buy goods in Kokrosono because there are so many items that are still suitable for use but the prices are very cheap. Pak Surwawi himself felt very helped by many PKL Kokrosono when he was about to buy items such as handyman tools such as measuring instruments because such an important item is the function of its use does not see the brand.

As for the negative impact of the existence of street vendors (PKL) along Madukoro road, it is clear that they are making the road conditions to a standstill and taking the rights of road users, because they sell on the shoulder of the road or on the sidewalk, and the other impacts that are caused are road conditions which became dirty because a lot of street vendors (PKL) who sell there are not neat and orderly and often if there are buyers on the roadside parking this also disturbs road users. But 
the obvious negative impact is the influence of residents around there, especially in RT03 RW06 where the head of the RT Pak Pras, there are many residents who even sell in Kokrosono and there have been citizens who were also subject to legal cases for being thieves and detainers of stolen montor. Residents around there even feel used to selling there because of its strategic location and urgency to meet the needs of life and economic needs.

The linkages of the PP Satpol parties here as law enforcers here are tasked with curbing the street vendors (PKL) based on Government Regulation No. 16 of 2018 concerning Satpol PP and using 2 (two) regional regulations to deal with the problem of street vendors, namely Regional Regulation No. 11 of 2000 concerning Regulation and Guidance of street vendors and SK Mayor / 511.3 / 1112 which was passed on 16 December 2016 concerning Land Determination of PKL Location in Semarang City. Satpol PP also frequently conducts operations or raids to curb the Kokrosono Street Vendors (PKL) but never give up, Satpol PP prefers administrative sanctions in the form of reprimands or warnings and confiscations. If the first, second and so on warnings do not have an effect, a temporary seizure of the confiscation of merchandise. Confiscated goods can be returned and taken within 10 days of confiscation, on the condition that there is a RT and RW Decree.

\section{Declaration of Conflicting Interests}

The authors state that there is no potential conflict of interest in the research, authorship, and/or publication of this article

\section{Funding}

None

\section{References}

Abdillah, R. (2017). Upaya Unit Patroli Satuan Sabhara Dalam Mencegah Kasus Pencurian
Kendaraan Bermotor Di Wilayah Hukum Polres Cilacap. Advances in Police Science Research Journal, 1(3), 1031-1084. Retrieved from

https://journal.akpol.ac.id/index.php/apsrj/ar ticle/view/96

Ali, R. N. (2017). Optimalisasi Patroli Dialogis Satuan Sabhara Polres Kudus dalam Mencegah Tindak Pidana Pencurian dengan Pemberatan. Indonesian Journal of Police Studies, 1(2), 523-570. Retrieved from https://journal.akpol.ac.id/index.php/ijps/arti cle/view/43

Andreaz, L. (2017). Optimalisasi Patroli Satuan Sabhara dalam Mencegah Tindak Pidana Pencurian dengan Pemberatan di Wilayah Hukum Polres Klaten: Optimization of Sabhara Unit Patrols in Preventing Crime of Theft with Weights in the Klaten PoliceJurisdiction. Advances in Police Science Research Journal, 1(1), 103-148. Retrieved from

https://journal.akpol.ac.id/index.php/apsrj/ar ticle/view/19

Arief, B.N. (2010). Kebijakan Legislatif dalam Penanggulangan Kejahatan dengan Pidana Penjara. Yogyakarta: Genta Publishing

Arifin, R. (2020). Legal Reform Discourse in Indonesia and Global Context: How Does The Law Respond to Crime. Journal of Law and Legal Reform, 1(2), 193-196. https://doi.org/10.15294/jllr.v1i2.37057

Arifin, R. (2020). Crimes and Society, How Do the Law Respond to Disruptive Conditions?. Law Research Review Quarterly, 6(1), i-iv. Retrieved from https://journal.unnes.ac.id/sju/index.php/sn h/article/view/37437

Arikunto, S. (2006). Prosedur Penelitian Suatu Pendekatan Pratik. Jakarta: PT. Rineka Cipta.

Bittikaka, F. (2017). Peran Bhabinkamtibmas Dalam Mencegah Curanmor Di Wilayah Hukum Polres Purworejo. Advances in Police Science Research Journal, 1(4), 1533-1598. Retrieved from

https://journal.akpol.ac.id/index.php/apsrj/ar ticle/view/105

Badan Pusat Statistik Jawa Tengah. (2017). Februari 2017, Tingkat Penggangguran Terbuka di Jawa Tengah sebesar 4,15 Persen. 
https://jateng.bps.go.id/pressrelease/2017/0

5/05/962/februari-2017-tingkat-

pengangguran-terbuka-di-jawa-tengah-

sebesar-4-15-persen.

Badan Pusat Statistik Jawa Tengah. (2017). Jumlah Penduduk dan Laju Pertumbuhan Penduduk Menurut Kabupaten/Kota di Provinsi Jawa Tengah 2015, 2016 dan 2017. https://jateng.bps.go.id/statictable/2017/10/ 26/1533/jumlah-penduduk-dan-lajupertumbuhan-penduduk-menurutkabupaten-kota-di-provinsi-jawa-tengah2015-2017.html.

Badan Pusat Statistik Jawa Tengah. (2017). Penduduk Berumur 15 Tahun Ke Atas yang Bekerja Selama Seminggu yang Lalu Menurut Lapangan Pekerjaan Utama dan Jenis Kelamin di Provinsi Jawa Tengah, 2007-2017. https://jateng.bps.go.id/statictable/2017/03/ 22/1479/penduduk-berumur-15-tahun-keatas-yang-bekerja-selama-seminggu-yanglalu-menurut-lapangan-pekerjaan-utamadan-jenis-kelamin-di-provinsi-jawa-tengah2007-2017.html

D'Este, R.. (2014). The Effect of Stolen Goods Markets on Crime: Evidence from a QuasiNatural Experiment. The Warwick Economics Research Paper Series (TWERPS) 1040, University of Warwick, Department of Economics.

https://ideas.repec.org/p/wrk/warwec/1040. html

Dirdjosisworo, S. (1976). Hukum dan Hukum Pidana. Bandung: PT. Sinar Baru.

Dermawan, M.K. (n.d). Modul 1: Ruang Lingkup Studi Kriminologi. http://repository.ut.ac.id/4563/2/SOSI4302M1.pdf

Galiani, S., Jaitman, L., \& Weinschelbaum, F. (2018). Crime and Durable Goods. LACEA Working Paper Series No. 0009 (July 2018), https://pdfs.semanticscholar.org/d031/f1503 327a41f8864e1bbee000f802922ca72.pdf

Gurvutch, G. (1961). Sociology of Law. Jakarta: Barata

Imballoo, I. (2017). Optimalisasi Patroli Roda Empat Satuan Sabhara dalam Mencegah Tindak Pidana Pencurian Kendaraan Bermotor di Wilayah Hukum Polres Kudus: Optimizing the Sabhara Unit's Four-Wheeled Patrol in
Preventing Criminal Acts of Motorized Vehicle Theft in the Jurisdiction of Kudus District Police. Police Studies Review, 1(1), 381-430. Retrieved from https://journal.akpol.ac.id/index.php/psr/arti cle/view/15

Isrohah, I. (2015). BAB II: Teori dan Perumusan Hipotesis. Malang: Universitas Muhammadiyah Malang.

Indonesian Criminal Code (Kitab Undang-Undang Hukum Pidana).

Maramis, F. (2012). Hukum Pidana Umum dan Tertulis di Indonesia. Jakarta: Raja Grafindo Persada.

Mardiani, M., Suhaimi, S., \& Mansur, T.M. (2018). Peranan Satuan Polisi Pamong Praja dalam Menata dan Membina Pedagang Kaki Lima di Kota Banda Aceh. Syiah Kuala Law Journal 2(2), 233-246. https://doi.org/10.24815/sklj.v2i2.11631

Millennia, N. I., Anan, Y., Lestari, I., Arifin, R., \& Hidayat, A. (2020). Punk Community in Criminology Study (Study in Ngaliyan District, Semarang City). Law Research Review Quarterly, 6(1), 37-52. https://doi.org/10.15294//rrq.v6i1.31232

Monika, V. et.al (2014). Hubungan Persepsi Tentang Reputasi Petugas Satpol PP dengan Kepatuhan Pada Pedagang Kaki Lima. Jurnal Riset Psikologi 3(2), 135-148.

Muhtada, D., \& Arifin, R. (2019). 'Penal Policy and the Complexity of Criminal Law Enforcement: Introducing JILS 4(1) May2019 Edition'. JILS (Journal of Indonesian Legal Studies) 4(01), 1 6.

DOI: https://doi.org/10.15294/jils.v4i01.30189

Mulyadi, L. (2010). Kajian Kritis dan Analitis Terhadap Dimensi Teori-Teori Kriminologi dalam Perspektif IImu Pengetahuan Hukum Pidana Modern. http://ptjambi.go.id/uploads/others/kajian_kritis_dan _analitis_terhadap_dimensi_teori__teori_kriminologi_dalam_perspektif_ilmu_p engetahuan_hukum_pidana_modern.pdf

Mustofa, G. K. (2017). Optimalisasi Penyuluhan Satuan Binmas Melalui Program Djimat dalam Pencegahan Tindak Pidana Pencurian Kendaraan Bermotor di Wilayah Hukum Polres Banyumas: Optimizing the Extension of Binmas Unit Through the Djimat Program 
in Preventing Criminal Acts of Motorized Vehicle Theft in the Jurisdcition of Banyumas District Police. Police Studies Review, 1(1), 145-208. Retrieved from https://journal.akpol.ac.id/index.php/psr/arti cle/view/11

Oktania, Z. (2017). Peran Bhabinkamtibmas dalam Mencegah Tindak Pindana Pencurian Kendaraan Bermotor (Curanmor) di Wilayah Hukum Polres Tegal. Advances in Police Science Research Journal, 1(2), 709-772. Retrieved

from https://journal.akpol.ac.id/index.php/apsrj/ar ticle/view/32

Pellokila, J. R. Z. (2017). Upaya Peningkatan Kinerja Unit Patroli Satuan Sabhara dalam Rangka Mencegah Tindak Pidana di Polres Sukoharjo.Indonesian Journal of Police Studies, 1(5). Retrieved from https://journal.akpol.ac.id/index.php/ijps/arti cle/view/64

Peraturan Pemerintah Nomor 16 Tahun 2018 tentang Satuan Polisi Pamong Praja Peraturan Daerah Nomor 11 Tahun 2000 tentang Peraturan dan Pembinaan Pedagang Kaki Lima

Prakoso, G. R. (2017). Optimalisasi Penyelidikan Intelijen dalam Penanggulangan Tindak Pidana Pencurian dengan Pemberatan di Wilayah Hukum Polsek Purwokerto Timur: Optimization of Intelligence Investigation in Handling the Theft of Crimes in the Jurisdiction of the East Purwokerto District Police. Police Studies Review, 1(1), 209-260. Retrieved from https://journal.akpol.ac.id/index.php/psr/arti cle/view/12

Prisma, Y. (2017). Optimalisasi Patroli Satuan Sabhara dalam Mencegah Terjadinya Tindak Pidana Pencurian dengan Pemberatan di Wilayah Hukum Polres Pekalongan. Advances in Police Science Research Journal, 1(2), 651$798 . \quad$ Retrieved from https://journal.akpol.ac.id/index.php/apsrj/ar ticle/view/31

Prodjodikoro, W. (1986). Asas-asas Hukum Pidana di Indonesia. Jakarta: Ghalia Indonesia

Saherodji, H. (1980). Pokok-Pokok Kriminologi. Jakarta: Aksara Baru.
Sahetapy, J.E. (1982). Parados dalam Kriminologi. Jakarta: Rajawali.

Sari, G.P. (2017). Eksistensi Pedagang Kaki Lima di Pasar Maling Wonokromo Surabaya. Thesis. Surabaya: Universitas Airlangga. http://journal.unair.ac.id/downloadfullpapers-kmnts44f076fdedfull.pdf

Sari, N.R. (2010). Efisiensi Penindakan Aksi Vandalisme Terhadap Ruang Publik di Kota Surakarta. Thesis, Surakarta: Universitas Sebelas Maret

Saputro, F.A. (2013). Peranan Satuan Polisi Pamong Praja dalam Mengimplementasikan Peraturan Daerah Tentang Pedagang Kaki Lima di Surakarta. Thesis, Semarang: Universitas Negeri Semarang

Setiadi, N.J. (2003). Perilaku Konsumen. Jakarta: Kencana.

Susilana, R. (nn). PM3 Modul Penelitian 5. Bandung: Fakultas IImu Pendidikan Universitas Pendidikan Indonesia

Sutton, M. (2017). Fencing and Stolen Goods Markets.

https://www.oxfordbibliographies.com/view/ document/obo-9780195396607/obo9780195396607-0219.xml.

SK Walikota/511.3/1112 yang disahkan pada tanggal 16 desember 2016 tentang Penetapan Lahan Lokasi PKL Kota Semarang

Syahputra, A. R. (2017). Optimalisasi Program Warkop Binmas Guna Meningkatkan Partisipasi Masyarakat dalam Menanggulangi Pencurian Kendaraan Bermotor di Wilayah Polres Kudus. Indonesian Journal of Police Studies, 1(2), 443-480. Retrieved from https://journal.akpol.ac.id/index.php/ijps/arti cle/view/41

Tamboto, E. W. (2017). Peran Bhabinkamtibmas Dalam Mencegah Tindak Pidana Pencurian Kendaraan Bermotor Di Wilayah Hukum Polsek Grogol Polres Sukoharjo. Advances in Police Science Research Journal, 1(4), $1357-$ 1398. Retrieved from https://journal.akpol.ac.id/index.php/apsrj/ar ticle/view/102

Tarigan, R. P. (2017). Optimalisasi Patroli Roda Empat Satuan Sabhara Dalam Mencegah Terjadinya Tindak Pidana Pencurian Kendaraan Bermotor (Curanmor) Di Wilayah Hukum Polres Purbalingga. Advances in 
Police Science Research Journal, 1(3), 1153$1210 . \quad$ Retrieved from https://journal.akpol.ac.id/index.php/apsrj/ar ticle/view/98

Widodo, A. (2000). Faktor-Faktor yang Mempengaruhi Pemilihan Lokasi Usaha Pedagang Kaki Lima (Studi Kasus: Kota Semarang). Thesis, Semarang: Universitas Diponegoro.

http://eprints.undip.ac.id/14439/

Wiyoso, W.T., \& Warsono, W. (2014). Faktor Yang Mempengaruhi Konsumen "Memilih Pasar Maling" Surabaya. Kajian Moral dan

Submitted June 28, 2019

Revision received January 12, 2020

Accepted April 15, 2020

\section{How to cite?}

Adiyatma, S. E., Purwoko, N. G., Pangestika, F. M., \& Kandiati, D. (2020). Society and Law Enforcement Personnel in Trading Stolen Goods. Law Research Review Quarterly 6(2), 101-116. https://doi.org/10.15294/Irrq.v6i2.31107.
Kewarganegaraan 2(2), 579-593.

https://jurnalmahasiswa.unesa.ac.id/index.p hp/jurnal-pendidikan-

kewarganegaraa/article/view/7851

Yulian, P. (2019). Tinjauan Yuridis Terhadap Pertanggungjawaban Pidana Penadah Barang Berharga Hasil Pencurian. Thesis, Surakarta: Universitas Slamet Riyadi Surakarta. 